Journal of Southeast Asian

\title{
Book Review: Contemporary Issues in Southeast Asian American Studies by Jonathan H. X. Lee and Roger V. Chung
}

Kathleen Nadeau

California State University, San Bernardino., knadeau@csusb.edu

Follow this and additional works at: https://docs.lib.purdue.edu/jsaaea

\section{Recommended Citation}

Nadeau, Kathleen (2011) "Book Review: Contemporary Issues in Southeast Asian American Studies by Jonathan H. X. Lee and Roger V. Chung," Journal of Southeast Asian American Education and Advancement: Vol. 6 : Iss. 1, Article 18.

DOI: $10.7771 / 2153-8999.1034$

Available at: https://docs.lib.purdue.edu/jsaaea/vol6/iss1/18

This document has been made available through Purdue e-Pubs, a service of the Purdue University Libraries. Please contact epubs@purdue.edu for additional information.

This is an Open Access journal. This means that it uses a funding model that does not charge readers or their institutions for access. Readers may freely read, download, copy, distribute, print, search, or link to the full texts of articles. This journal is covered under the CC BY-NC-ND license. 


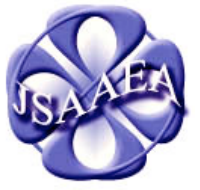

Volume 6 (2011)

\section{Journal of Southeast Asian American} Education \& Advancement
A peer-reviewed scholarly journal published by the National Association for the Education \& Advancement of Cambodian, Laotian, and Vietnamese Americans (NAFEA)

Lee, Jonathan H. X., \& Chung, Roger V. (Eds.). (2011). Contemporary issues in Southeast Asian American Studies. San Diego, CA: Cognella Academic Publishing. 170 pp. \$ 41.95 (Paperback). ISBN: 978-1-60927-706-2.

\author{
Reviewed by \\ Kathleen Nadeau \\ California State University, San Bernardino
}

Contemporary Issues in SOUTHEAST A ASIĀN AMERICAN STUDIES

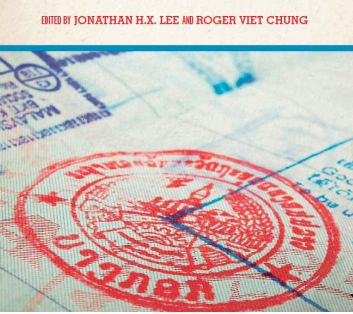

Contemporary Issues in Southeast Asian American Studies consists of a series of short vignettes that would be a wonderful accompaniment for a more comprehensive reader on the subject. This textbook was designed for classroom use to expose students to some of the issues and concerns of the post-1965 immigrant experiences of Southeast Asians coming to the United States. While the pre-1965 histories of Asian Americans already has been substantially and authoritatively written, especially by Ronald Takaki, the more recent histories of Southeast Asian Americans awaits to be told. This reader provides some glimpses as to what this history might include.

The brief introduction points to the complexities and diversities in the experiences of recent immigrants from Southeast Asia. For example, while some 1,146,650 refugees from Vietnam, Laos, and Cambodia came to the United States, from 1975 into the turn of the new millennium, this does not mean that all new immigrants from these countries are refugees. Another example, many Chinese Vietnamese and Chinese Cambodians, among other Southeast Asian Chinese, choose to self-identify as ethnic Chinese, which complicates the veracity of census survey information on the different Asian American populations.

Chapter 1 reprints the Refugee Act of 1975, the Refugee Act of 1980 and the Amerasian Homecoming Act of 1987. Chapters 2 and 3 provide useful discussions on "Southeast Asian American Wars and Movements" and the "Socioeconomic Status of Indochinese Refugees," respectively. Chapter 4 provides an excerpt from Time Magazine on a young deportee's success story as a break dancer, after being deported to Cambodia; but this is not the norm for many youth (e.g., holding refugee status or permanent residency status) who have been deported for committing criminal offenses before, legally, becoming citizens.

Chapter 5 reprints a news article on a dispute among Vietnamese Americans over the naming of "Little Saigon" because of its anti-communist connotation and the fact that the business district, it refers to, is no longer, exclusively, Vietnamese American but, rather,

\title{
@)
}

SOMERIGHISRESEREED Readers are free to copy, display, and distribute this article, as long as the work is attributed to the author(s) and the Journal of Southeast Asian American Education \& Advancement, it is distributed for noncommercial purposes only, and no alteration or transformation is made in the work. More details of this Creative Commons license are available at http://creativecommons.org/licenses/by-nc-nd/3.0/. All other uses must be approved by the author(s) or JSAAEA. 
multiethnic. Chapter 6 reprints an excerpt on the difficulty Burmese poses for census takers because Burmese Americans, rarely, use last names. While chapter 11 concerns the hazards faced by Vietnamese American women working in the nail salon industry, Chapter 12 reprints a news release on former Thai slave laborers who were rescued from an El Monte sweatshop.

Subsequent chapters, also, feature some lively reading: Chapter 13 reprints a news release that examines issues pertaining to welfare reform and its effects on Vietnamese clients, who migrated to the United States in the early 1990s; Chapter 14 looks at some of the tensions and conflicts, and capital crimes, that occurred between Hmong Americans, "White" Americans, and Native Americans over hunting rights in Northern Wisconsin; Chapter 15 provides an original essay on the question of representation and the depiction of queer Pinoys in Filipino American films; Chapter 16 reprints a news brief on a Laotian American community's fight for social justice against Chevron; and Chapter 17 reprints a research article on Vietnamese American gang activities. Each chapter also includes study questions.

The book has a few slight drawbacks, but again, not to outweigh its inherent value considering that it was prepared for in-class use. Chapters 7-10 seem somewhat out of place. Chapter 7 reads more like a brochure for the Thai temple and cultural center that it pertains to, while Chapters 8-10 are somewhat overly descriptive and don't match well with the swift and informative style of the rest of the reader.

All in all, this is a wonderful little book of short vignettes on current Southeast Asian American issues and concerns. This is not a comprehensive or complete book but a course textbook that would make a delightful companion text for a history book in Southeast Asian American Studies. As a preliminary collection of informative and eye-opening vignettes on current Southeast Asia American issues, it will appeal to scholars of Ethnic Studies and Asian American Studies and community organizers and the general public.

\section{Reference}

Takaki, R. (1998). Strangers from a different shore: A history of Asian Americans (Updated and Revised ed.). New York: Back Bay Books.

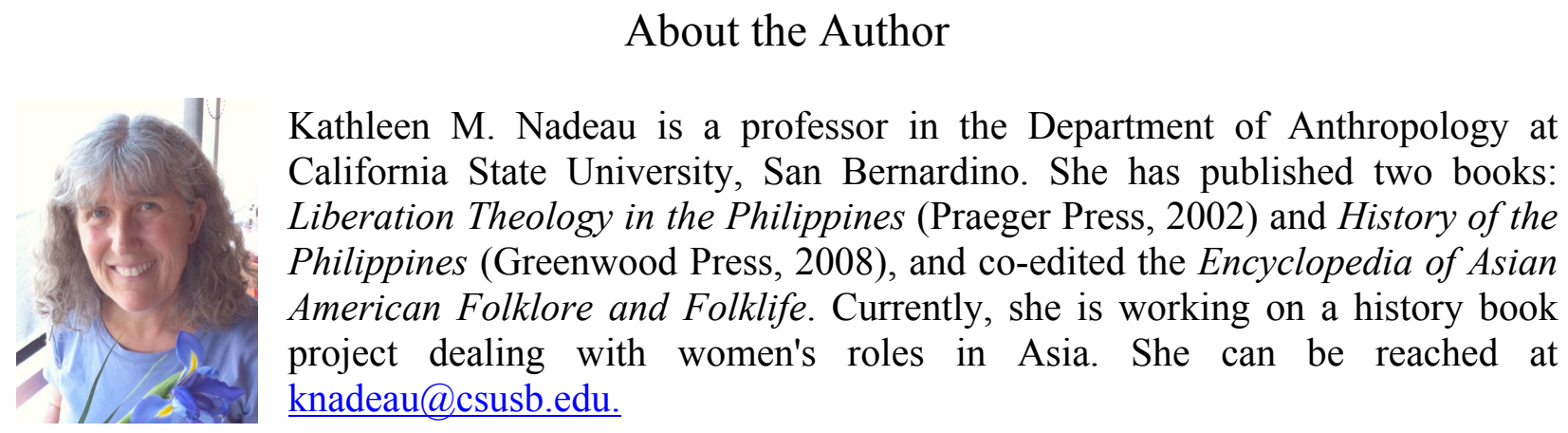




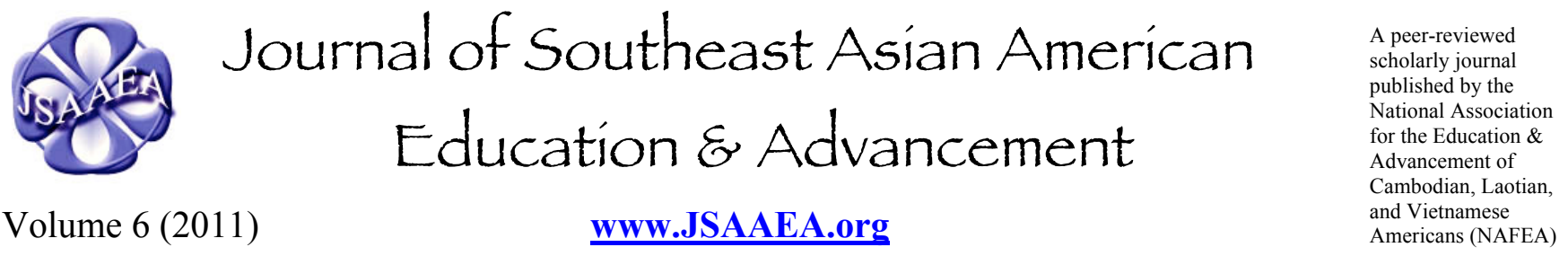

\author{
Editor \\ Dr. Wayne E. Wright \\ University of Texas, San Antonio \\ Associate Editors \\ Dr. Chhany Sak-Humphry \\ University of Hawaii \\ Dr. KimOanh Nguyen-Lam \\ California State University, Long Beach \\ Book Review Editor \\ Dr. Vichet Chhuon \\ University of Minnesota \\ Creative Works Editor \\ Bryan Thao Worra \\ Lao Assistance Center \\ Special Advisor \\ Gregory Green \\ Curator, Echols Collection on Southeast Asia, Cornell University Library \\ Journal Manager \\ Sovicheth Boun \\ University of Texas, San Antonio
}

Comments and questions for the editorial staff may be directed to jsaaea@lists.sis.utsa.edu

\title{
Editorial Review Board
}

\author{
Dr. Steve Arounsack \\ California State University, Stanislaus \\ Dr. Phala Chea \\ Lowell Public Schools \\ Dr. Loan Dao \\ Cancer Prevention Institute of California \\ Dr. Sophal Ear \\ U.S. Naval Postgraduate School \\ Dr. Nancy H. Hornberger \\ University of Pennsylvania \\ Dr. Peter Nien-Chu Kiang \\ University of Massachusetts, Boston
}

Dr. Carl L. Bankston III

Tulane University

Dr. George Chigas

University of Massachusetts, Lowell

Dr. Changming Duan

University of Missouri, Kansas City

Dr. Jeremy Hein

University of Wisconsin - Eau Claire

Dr. Samlong Inthaly

Minneapolis Public Schools

Dr. Kevin K. Kumashiro

University of Illinois, Chicago 


\author{
Dr. Jonathan H. X. Lee \\ San Francisco State University \\ Dr. Sue Needham \\ California State University, Dominguez Hills \\ Dr. Max Niedzwiecki \\ Daylight Consulting Group \\ Dr. Clara Park \\ California State University, Northridge \\ Dr. Mark Pfeifer \\ Texas A\&M University, Corpus Christi \\ Dr. Bounlieng Phommasouvanh \\ Minnesota Department of Education \\ Dr. Kalyani Rai \\ University of Wisconsin, Milwaukee \\ Dr. Fay Shin \\ California State University, Long Beach \\ Dr. Cathy J. Schlund-Vials \\ University of Connecticut, Storrs \\ Dr. Yer J. Thao \\ Portland State University \\ Dr. Myluong Tran \\ San Diego State University \\ Dr. Khatharya Um \\ University of California, Berkeley \\ Dr. Linda Trinh Vo \\ University of California, Irvine \\ Dr. Zha Blong Xiong \\ University of Minnesota
}

\author{
Dr. Stacey Lee \\ University of Wisconsin, Madison \\ Dr. Bic Ngo \\ University of Minnesota \\ Dr. Leakhena Nou \\ California State University, Long Beach \\ Dr. Isabelle Thuy Pelaud \\ San Francisco State University \\ Dr. Loan T. Phan \\ University of New Hampshire \\ Dr. Karen Quintiliani \\ California State University, Long Beach \\ Dr. Angela Reyes \\ Hunter College, The City University of New York \\ Dr. Nancy J. Smith-Hefner \\ Boston University \\ Dr. Christine Su \\ Ohio University \\ Dr. Loan Tran \\ University of California, Riverside \\ Dr. Tinou Tran \\ Alief Independent School District \\ Dr. Phitsamay Sychitkokhong Uy \\ University of Massachusetts, Lowell \\ Dr. Terrence G. Wiley \\ Center for Applied Linguistics \\ Dr. Kou Yang \\ California State University, Stanislaus
}

\section{Doctoral Student Editorial Review Board}

\author{
Keo Chea-Young \\ University of Pennsylvania \\ Ketmani Kouanchao \\ California State University, Fullerton \\ Polinda Keo \\ University at Albany \\ Ravy Lao \\ University of California, Santa Barbara \\ Thien-Huong Ninh \\ University of Southern California \\ Malaphone Phommasa \\ University of California, Santa Barbara \\ Rassamichanh Souryasack \\ University of California, Santa Barbara \\ Alisia Tran \\ University of Minnesota \\ Silvy Un \\ University of Minnesota
}

\author{
Annie BichLoan Duong \\ San Joaquin County Office of Education \\ Peter Tan Keo \\ Columbia University \\ Ha Lam \\ Arizona State University \\ Monirith Ly \\ Texas State University-San Marcos \\ Giang Pham \\ University of Minnesota \\ Vanna Som \\ Harvard University \\ Somongkol Teng \\ University of Minnesota \\ Krissyvan Truong \\ Claremount Graduate University \\ Yang Sao Xiong \\ University of California, Los Angeles
}

